JOINING URANIUM TO STEEL

M. A. Perkins

May 1976

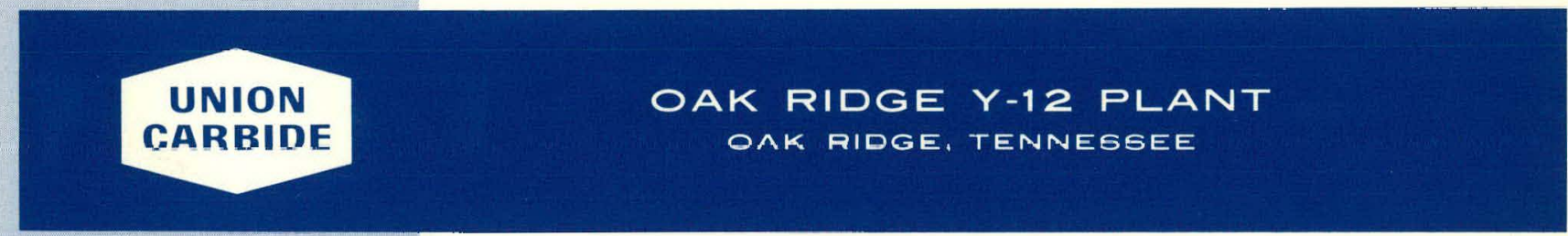

prepared for the U.S. ENERGY RESEARCH AND DEVELOPMENT ADMINISTRATION under U.S. GOVERNMENT Contract W-7405 eng 26

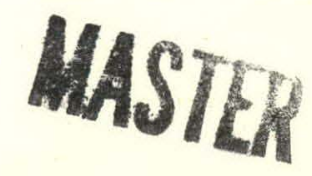




\section{DISCLAIMER}

This report was prepared as an account of work sponsored by an agency of the United States Government. Neither the United States Government nor any agency Thereof, nor any of their employees, makes any warranty, express or implied, or assumes any legal liability or responsibility for the accuracy, completeness, or usefulness of any information, apparatus, product, or process disclosed, or represents that its use would not infringe privately owned rights. Reference herein to any specific commercial product, process, or service by trade name, trademark, manufacturer, or otherwise does not necessarily constitute or imply its endorsement, recommendation, or favoring by the United States Government or any agency thereof. The views and opinions of authors expressed herein do not necessarily state or reflect those of the United States Government or any agency thereof. 


\section{DISCLAIMER}

Portions of this document may be illegible in electronic image products. Images are produced from the best available original document. 
Reference to a company or product name does not imply approval or recommendation of the product by Union Carbide Corporation or the U.S. Energy Research and Development Administration to the exclusion of others that may meet specifications.

Printed in the United States of America. Available from National Technical Information Service

U.S. Department of Commerce

5285 Port Royal Road, Springfield, Virginia 22161

Price: Printed Copy $\$ 4.00$, Microfiche $\$ 2.25$

3.

This report was prepared as an account of work sponsored by the United States Government. Neither the United States nor the Energy Research and Development Administration/United States Nuclear Regulatory Commission, nor any of their employees, nor any of their contractors, subcontractors, or their employees, makes any warranty, express or implied, or assumes any legal liability or responsibility for the accuracy, completeness or usefulness of any information, apparatus, product or process disclosed, or represents that its use would not infringe privately owned rights. 


\title{
JOINING URANIUM TO STEEL
}

\author{
M. A. Perkins
}

Metallurgical Development Department Y-12 Development Division

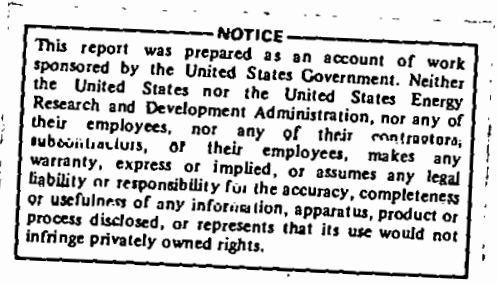

Oak Ridge Y.12 Plant

P. O. Box Y, Oak Ridge, Tennessee 37830

Prepared for the US Energy Research and Development Administration

Under UE Govornment Contract W.7105-eng-36 


\begin{abstract}
A method has been devised which will allow the joining of uranium to steel by fusion welding through the use of an intermediate material. Uranium-0.5 titanium was joined to AISI $304 \mathrm{~L}$ stainless steel by using a vanadium insert. Also, a method is now available for selecting possible filler metals when two entirely dissimilar metals need to be joined. This method allows a quantitative ranking to be made of the possible filler metals and thus the most likely candidate can be selected.
\end{abstract}




\section{CONTENTS}

SUMMARY ................................. 4

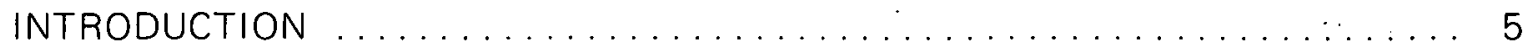

JOINING URANIUM TO STEEL $\ldots \ldots \ldots \ldots \ldots \ldots \ldots \ldots \ldots \ldots \ldots \ldots$

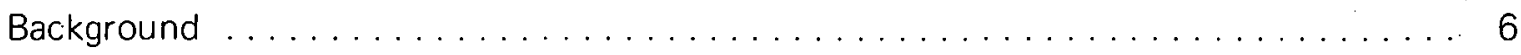

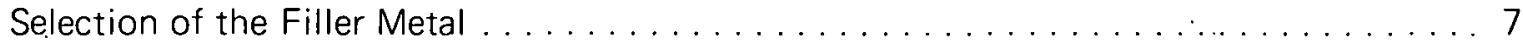

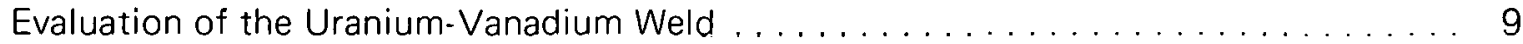

Evaluation of the Vanadium-Stainless Steel Weld . . . . . . . . . . . . . . . . . 10

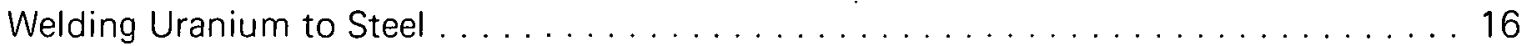

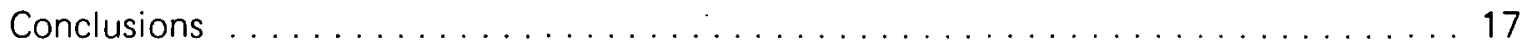

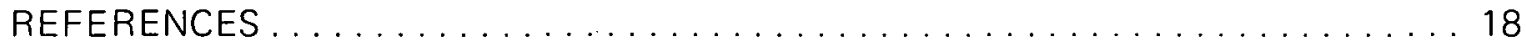

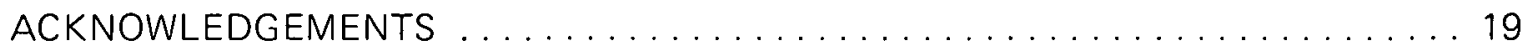




\section{SUMMARY}

Work was undertaken to develop a capability to join uranium to 'steel by some fusion-welding process. Because of the welding incompatibility of uranium and steel, a filler metal that is compatible with both metals is required.

A method was devised which indicated that vanadium was the prime candidate for such a filler metal. Evaluations were made of welding uranium-0.5 titanium alloy to AISI $304 \mathrm{~L}$ stainless steel, with vanadium as the filler, and the potential problem areas identified: Uranium-0.5 titanium was also joined to $304 \mathrm{~L}$ stainless steel using a vanadium insert. 


\section{INTRODUCTION}

At present, uranium and steel cannot be joined by any reliable, adequate-strength method. Judicious choice of a filler metal could greatly enhance the strength levels achievable in uranium-to-steel joints. While other joining methods might require the heating of large masses of material or involve complicated joint configurations, fusion welding would provide greater joining flexibility and could open limitless new applications. As a bonus to a fusion-welding process, a joint is produced which is normally considered to be the optimum in long-term reliability if properly qualified for the service conditions.

Work was undertaken to develop a method for fusion welding uranium to steel. While this report does not pretend to present an optimized process, it does present a process which, when fully developed for a specific application, could be useful. 


\section{JOINING URANIUM TO STEEL}

\section{BACKGROUND}

While it may be desirable to join uranium to steel, serious problems arise due to the metallurgical incompatibility of iron and uranium. As can be seen in Figure 1, the uranium-iron phase diagram, (1) low iron concentrations present those conditions which most investigators believe lead to hot cracking; namely, low solid solubility and a wide freezing range. $(2-6)$ Investigation of the uranium-iron system at low concentrations has established the presence of thin liquid films; and, consequently, susceptibility to hot cracking. (7) This investigation also established that as the level of the eutectic increases in the microstructure, the susceptibility to hot cracking decreases.

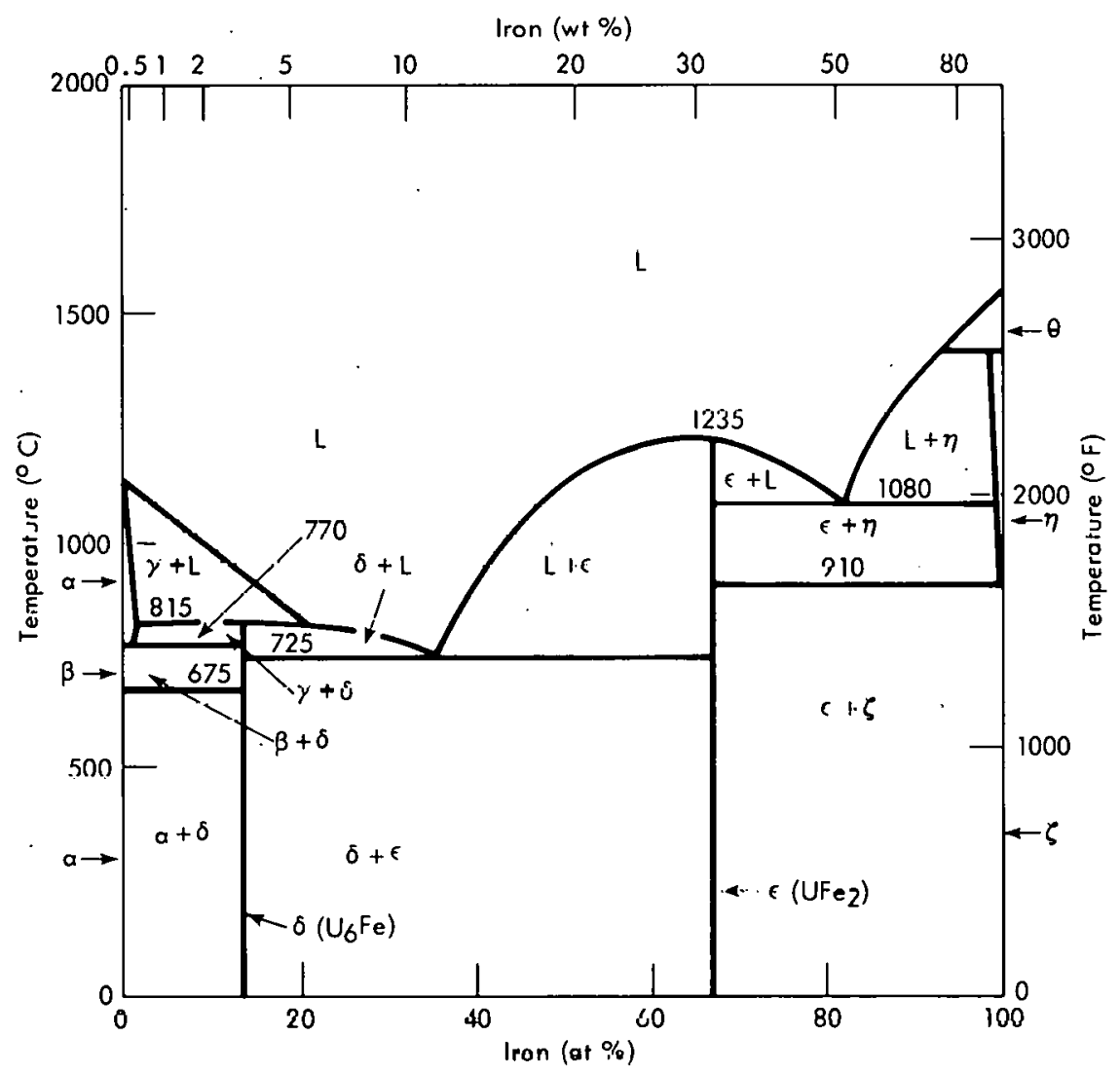

Figure 1. THE URANIUM-IRON PHASE DIAGRAM. (Source: Holden(1))

If an attempt is made to weld uranium directly to iron, a weldment containing a nominal 50 - 50 volume percent mixture ( $30 \mathrm{wt} \% \mathrm{Fe}, 70 \mathrm{wt} \% \mathrm{U})$ would be obtained. The usefulness of the weldment would depend on the properties of a microstructure composed of $U_{6} \mathrm{Fe}$ and UFe2, two intermetallic compounds. Any microstructure composed of two intermetallic compounds would certainly be suspect. In addition, hot cracking could be a continual problem due to the compositional variations in the unmixed region of the weld and liquation of grain boundaries in the heat-affected zone. 
This incompatibility requires that a dissimilar filler metal be found for making fusion welds between uranium and steel. In order to achieve quality welds, considerable attention must be paid to the physical, mechanical, and metallurgical properties of uranium, iron, and the third dissimilar metal to be joined.

\section{SELECTION OF THE FILLER METAL}

Of primary importance in dissimilar-metal welding is the metallurgical compatibility of the metals. While physical and mechanical properties are important, problems associated with them can normally be overcome by the proper welding procedures. Problems associated with the metallurgical compatibility of the metals are more serious and more subtle. Thus, it is desirable that when welding dissimilar metals they exhibit a strong tendency toward solid solubility and little tendency toward intermetallic compound formation. (8)

While the various phase diagrams would readily show whether two metals exhibited a tendency toward solid solubility, the large number of combinations of metals to be examined seemed to dictate that a more orderly approach to the selection of a filler metal be taken. In addition, some type of quantitative ranking would be an advantage in choosing the most likely filler-metal candidate.

The extent to which two metals tend to form solid solutions and hence not form intermetallic compounds is governed by four factors, namely: (9) (1) atomic radii, (2) electronegativities, (3) valences, and (4) crystal structures.

Hume-Rothery found that the extent of primary solid solution is seriously hindered whenever the disparity in atomic radii exceeds $15 \%$. Gordy developed the electronegativity scale which, when two metals are compared, would give an indication of the heat evolved when a chemical bond is formed between them. Thus, the electronegativities should be near the same value or the heat of formation becomes large and exothermic, and a stable compound is formed. The valence is used in calculating the electronegativities; therefore, the valences should be the same in order for the electronegativities to be close. Finally, the crystal structures of the two metals should be the same or closely related because large crystal-structure transitions are not possible during solidification, especially the nonequilibrium cooling experienced during welding.

As a starting place for finding a filler metal, metals with a known or likely compatibility with iron $(10)$ were compared on the basis of the four factors just enumerated which influence solid solubility. First, the atomic radii were compared. To simultaneously satisfy the criteria of a radius difference of no greater than $15 \%$ with uranium and iron, the potential filler metal would have to fall within an atomic radius band of 1.17 to $1.46 \AA$. Table 1 lists the atomic radii of potential filler metals; and, as can be readily seen, all of these potential fillers satisfy this condition except for lead and gold, which can be eliminated. Also worth noting is that an atornic radius of $1.32 \AA$ would be ideal.

A comparison of the valences of the filler-metal candidates with uranium and iron does not eliminate any metal. Table 2 lists Pauling's values for the metallic valences. Due to the similar valences, the electronegativities, listed in Table 3, would be expected to be close, and indeed they are. 
Table 1

GOLDSCHMIDT ATOMIC RADII AT ROOM TEMPERATURE

(For Coordination Number 12)

\begin{tabular}{lc}
\hline Element & $\begin{array}{c}\text { Radius (1) } \\
(\mathcal{R})\end{array}$ \\
\hline $\mathrm{Au}$ & \\
$\mathrm{Co}$ & 1.46 \\
$\mathrm{Cr}$ & 1.25 \\
$\mathrm{Cu}$ & 1.30 \\
$\mathrm{Fe}$ & 1.28 \\
$\mathrm{Mn}$ & 1.26 \\
$\mathrm{Mo}$ & 1.35 \\
$\mathrm{Ni}$ & 1.39 \\
$\mathrm{~Pb}$ & 1.24 \\
$\mathrm{Pt}$ & 1.75 \\
$\mathrm{U}$ & 1.39 \\
$\mathrm{~V}$ & 1.38 \\
\hline
\end{tabular}

(1) Source: Darkin and Gurry. (9)

Finally, Table 4 lists the room-temperature crystal structures. None of the possible filler candidates match uranium's orthorhombic crystal structure. Nickel, copper, platinum, and cobalt would normally be eliminated from this final list because the transition from face-centered cubic or hexagonal to body-centered cubic cannot be made. However, in the case of austenitic stainless stccls (which are of interest), the crystal structure is face-centered cubic and thus platinum, nickel, and ronner remain as possible choices.
Table 2

PAULING'S VALUES FOR METALLIC VALENCE

\begin{tabular}{ll}
\hline Elcment & Value (1) \\
\cline { 2 - 3 } $\mathrm{Co}$ & \\
$\mathrm{Cr}$ & 6 \\
$\mathrm{Cu}$ & 6 \\
$\mathrm{Fe}$ & 5.44 \\
$\mathrm{Mn}$ & 5.78 \\
$\mathrm{Mo}$ & 6 \\
$\mathrm{Ni}$ & 6 \\
$\mathrm{Pt}$ & 6 \\
$\mathrm{U}$ & 6 \\
$\mathrm{~V}$ & 5.78 \\
\hline
\end{tabular}

(1) Source: Darkin and Gurry. (9)

Table 3

PAULING'S VALUES FOR ELECTRONEGATIVITY

\begin{tabular}{lc}
\hline Element & Value(1) \\
\hline $\mathrm{Co}$ & \\
$\mathrm{Cr}$ & 1.8 \\
$\mathrm{Cu}$ & 1.6 \\
$\mathrm{Fe}$ & 1.9 \\
$\mathrm{Mn}$ & 1.8 \\
$\mathrm{Mo}$ & 1.5 \\
$\mathrm{Ni}$ & 1.8 \\
$\mathrm{Pt}$ & 1.8 \\
$\mathrm{U}$ & 2.2 \\
$\mathrm{~V}$ & 1.7 \\
\hline
\end{tabular}

(1) Source: Periodic Table of the Elements; SargentWelch Scientific Corripanty. Chicayo (1968).

A check of the phase diagrams of the potential fillers with uranium was made to see if any obvious incompatibilities existed. Manganese and nickel were eliminated because they both

Tabie 4

ROOM-TEMPERATURE CRYSTAL STRUCTURES

\begin{tabular}{ll}
\hline Flement & \multicolumn{1}{c}{ Structuro } \\
\hline $\mathrm{Co}$ & Hexagonal. \\
$\mathrm{Cr}$ & Body-Centered Cubic \\
$\mathrm{Cu}$ & Face-Centered Cubic \\
$\mathrm{Fe}$ & Body-Centered Cubic \\
$\mathrm{Mn}$ & Cubic \\
$\mathrm{Mo}$ & Body-Centered Cubic \\
$\mathrm{Ni}$ & Face-Centered Cubic \\
$\mathrm{Pt}$ & Face-Centered Cubic \\
$\mathrm{U}$ & Orthorhombic \\
$\mathrm{V}$ & Body-Centered Cubic \\
\hline
\end{tabular}
form series of intermetallic compounds with uranium (manganese-UศMn, UMn2; nickelU6 $\mathrm{Ni}$, Unig, U5Ni7, UNi2, UNi5). Copper was eliminated because the liquids are immiscible and UCu this total evaluation, vanadium, platinım, molybdenum, and chromium appeared to be yood filler rnctul candidates.

A comparisnn of the physical and mechanical properties was made with particular emphasis on thermal diffusivity, coefficient of linear thermal expansion, and strength. From this comparison, 
molybdenum was eliminated because of its low coefficient of thermal expansion and platinum and chromium because of their low strength. Vanadium then remained as the prime candidate for a filler metal. Table 5 provides a compilation of the physical and mechanical properties of the metals in question.

\section{EVALUATION OF THE URA- NIUM-VANADIUM WELD}

To examine the metallurgical compatibility of the metals, butt joints were electron-beam welded between the dissimilar metals. $\wedge$ butt joint was chosen because it tends to simplify the experiment and causes the joint geometry to be a less potent factor. Since vanadium metal was available in 2.083- $\mathrm{mm}$ plate, butt joints in this thickness were chosen for examination. A uranium- $0.5 \mathrm{wt} \%$ titanium alloy (U-0.5 Ti) was also readily available in approximately the same thickness, so it was chosen for study.

A single-pass electron-beam weld was made between 2.083-mm plates of vanadium and U-0.5 Ti. The welding parameters were: $100 \mathrm{kV}, 10 \mathrm{~mA}$, a sharp focus, and a speed of 76.2 $\mathrm{cm} / \mathrm{min}$. The plates were tightly clamped in a welding fixture so that a high degree of restraint was placed on the plates to promote cracking, if such a tendency existed. Visual and dye-penetrant examination of the welds failed to reveal any cracks.

Figure 2 is a photomicrograph of a weld. The fusion zone's lack of symmetry is to be expected due to the substantial difference in melting points of the two metals $\left(U-1132^{\circ} \mathrm{C}\right.$; $\left.\mathrm{V}-1900^{\circ} \mathrm{C}\right)$. Photomicroscopy revealed little information about the weld-metal composition, except for the prominent columnar dendritic structure evident in Figures 3 and 4 , so an electron-microprobe analysis of the weld metal was made. Figure 5 reveals the results of the analysis. Qualitative results of this analysis indicated a vanadium-rich dendritic phase in a uranium-rich matrix. Quantitative analysis of the weld metal, exclusive of the dendritic phase, gave the following results: $U, 94.9 \pm 1.3$ wt \%; $V, 3.5 \pm 1.1$ wt \%; Ti, $0.28 \pm 0.06$ wt \%. Due to the small size of the dendrites, it was not possible to obtain a quantitative analysis of the dendritic phase. However, since this was a welded butt joint between two plates, the nominal weld-metal composition would be expected to be approximately a 50 - 50 vol \% mixture ( 24 wt \% V, 76 wt \% U). Referring to Figure 6 (the uranium-vanadium phase diagram), the dendrites would be expected to be the $\delta$ phase composed of approximately $85 \mathrm{wt} \%$ vanadium and $15 \mathrm{wt} \%$ uranium, neglecting the titanium. The matrix composition corresponds almost directly with the eutectic composition.

A hardness traverse was made of the weld shown in Figure 2. Diamond-pyramid hardness (DPH) values, using a 500-gram Inad, were as follows: 


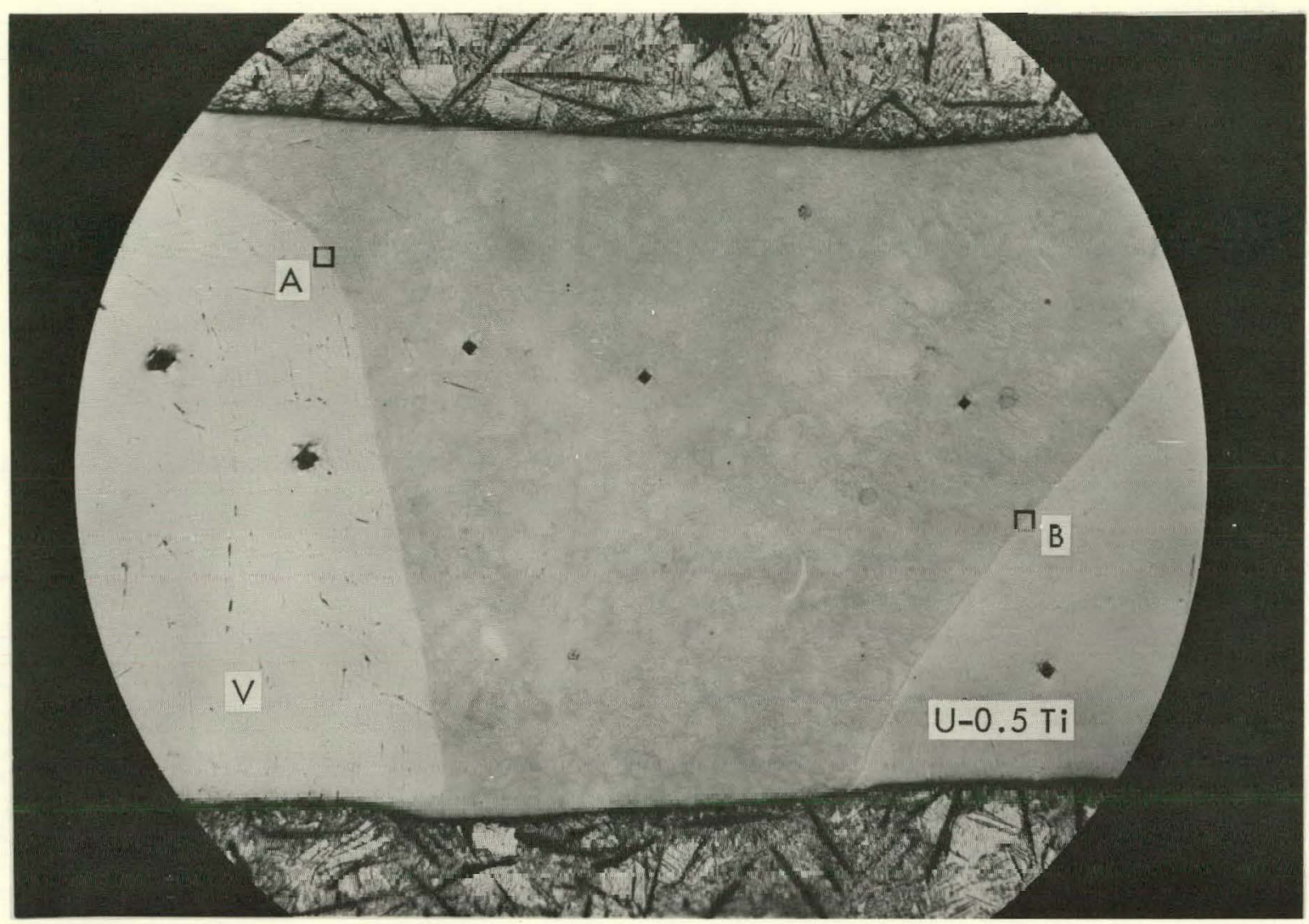

MS-75-0050-4

Figure 2. PHOTOMICROGRAPH OF A VANADIUM/URANIUM-0.5 TITANIUM WELD WITH HARDNESS INDENTATIONS. (Enlargements of Areas A and B are Provided in Figures 3 and 4; As Polished; Bright Field Illumination; 35X)

Uranium Base Metal

$\mathrm{DPH}$

$261,263,259$
Weld

$309,337,410$
Vanadium Base Metal

$133,130,151$

Thus, no unusual hardening took place in the weld. Four transverse tensile specimens were machined from a weld and tested; Table 6 summarizes the results. For this preliminary evaluation, uranium-vanadium welds appear to be satisfactory.

\section{EVALUATION OF THE VANADIUM- STAINLESS STEEL WELD}

Due to the interest in stainless steels, two were chosen for investigation-AISI 304L and ARMCO 21-6-9. As with the uraniumvanadium welds, butt joints between 2.083 $\mathrm{mm}$ 304L, 21-6-9, and vanadium plates were welded. Single-pass electron-beam

Table 6

TRANSVERSE TENSILE PROPERTIES OF A VANADIUM/URANIUM- 0.5

IIIANIUM WELD

\begin{tabular}{cccc}
\hline & $\begin{array}{c}\text { Tensile } \\
\text { Strength } \\
(\mathrm{MPa})\end{array}$ & $\begin{array}{c}\text { Yield Strength (1) } \\
(\mathrm{MPa})\end{array}$ & $\begin{array}{c}\text { Elongation (2) } \\
(\%)\end{array}$ \\
\hline & & \\
& 302.0 & 227.5 & 21.0 \\
326.8 & 263.4 & 19.0 \\
313.7 & 245.5 & 200 \\
& 308.2 & 253.7 & 20.5 \\
Average & 312.6 & 247.5 & 20.1 \\
\hline
\end{tabular}

(1) At $0.2 \%$ offset.

(2) In a 25.4-mm gage length. 


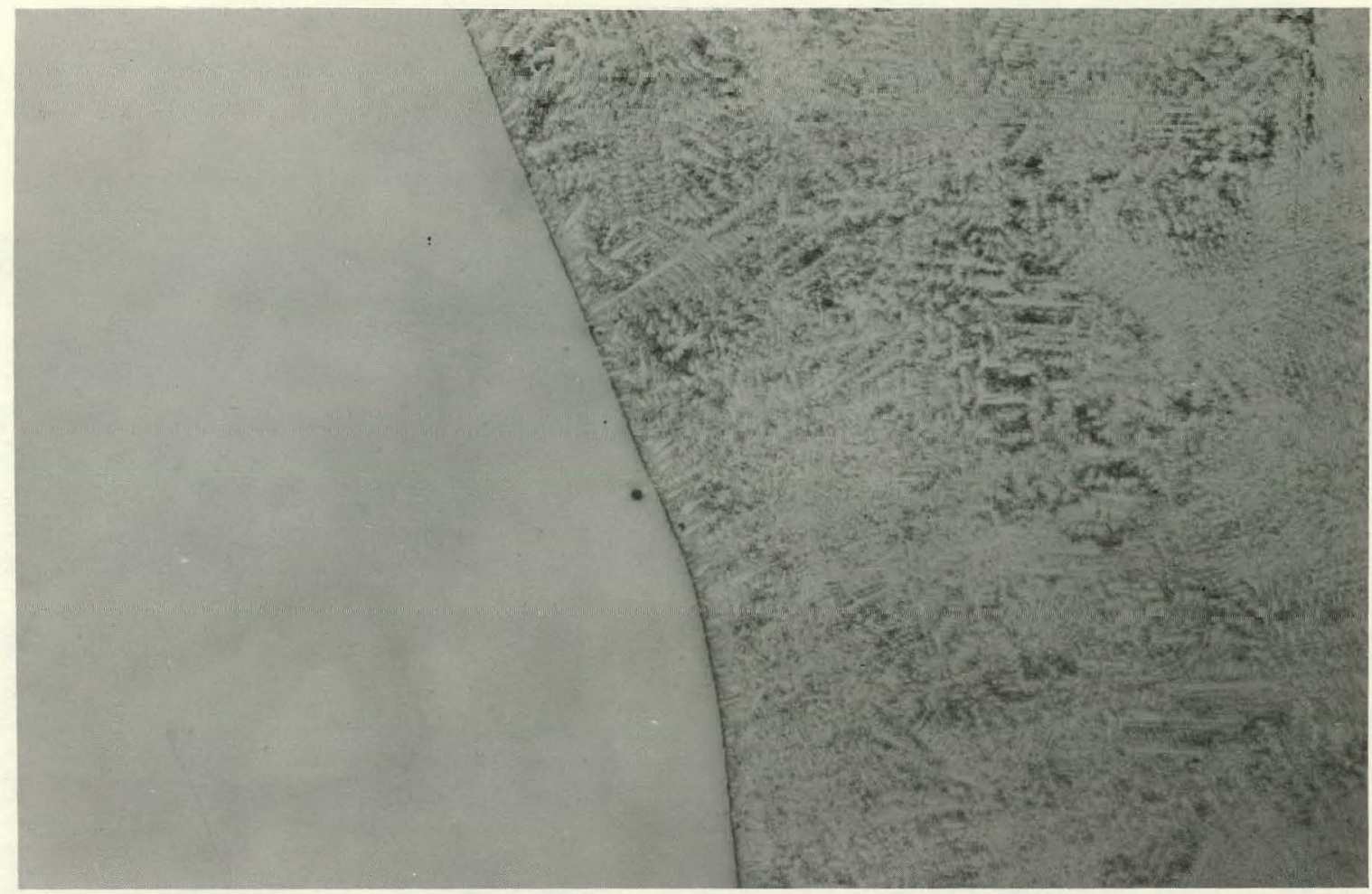

MS-74-1010-2

Figure 3. PHOTOMICROGRAPH OF AREA "A", FIGURE 2. (Columnar Dendritic Structure in the Fusion Zone is Quite Evident; As Polished; Bright Field Illumination; 400X)

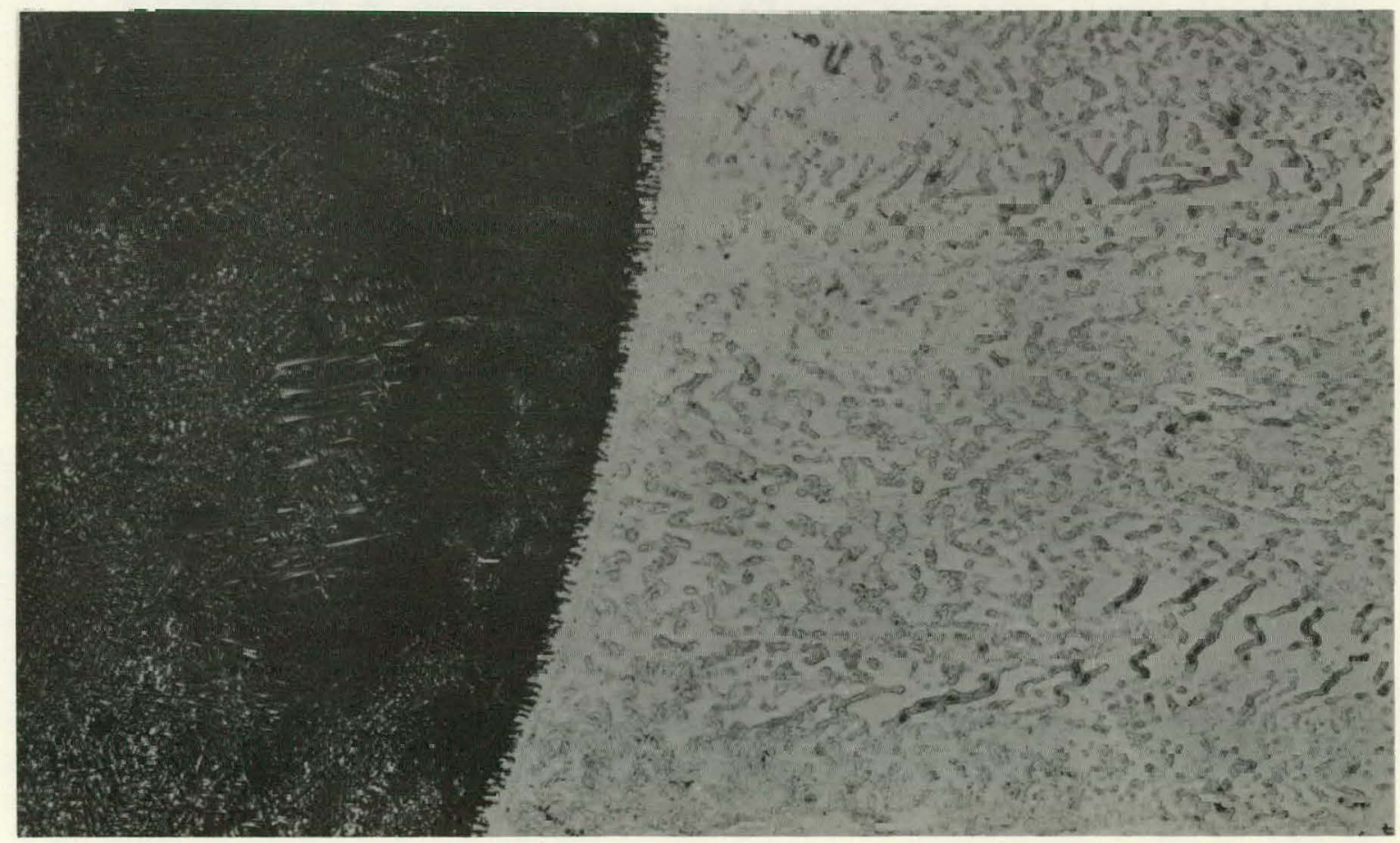

Figure 4. PHOTOMICROGRAPH OF AREA "B", FIGURE 2. (Etched; Bright Field Illumination; 400X)

MS-74-1010-4 


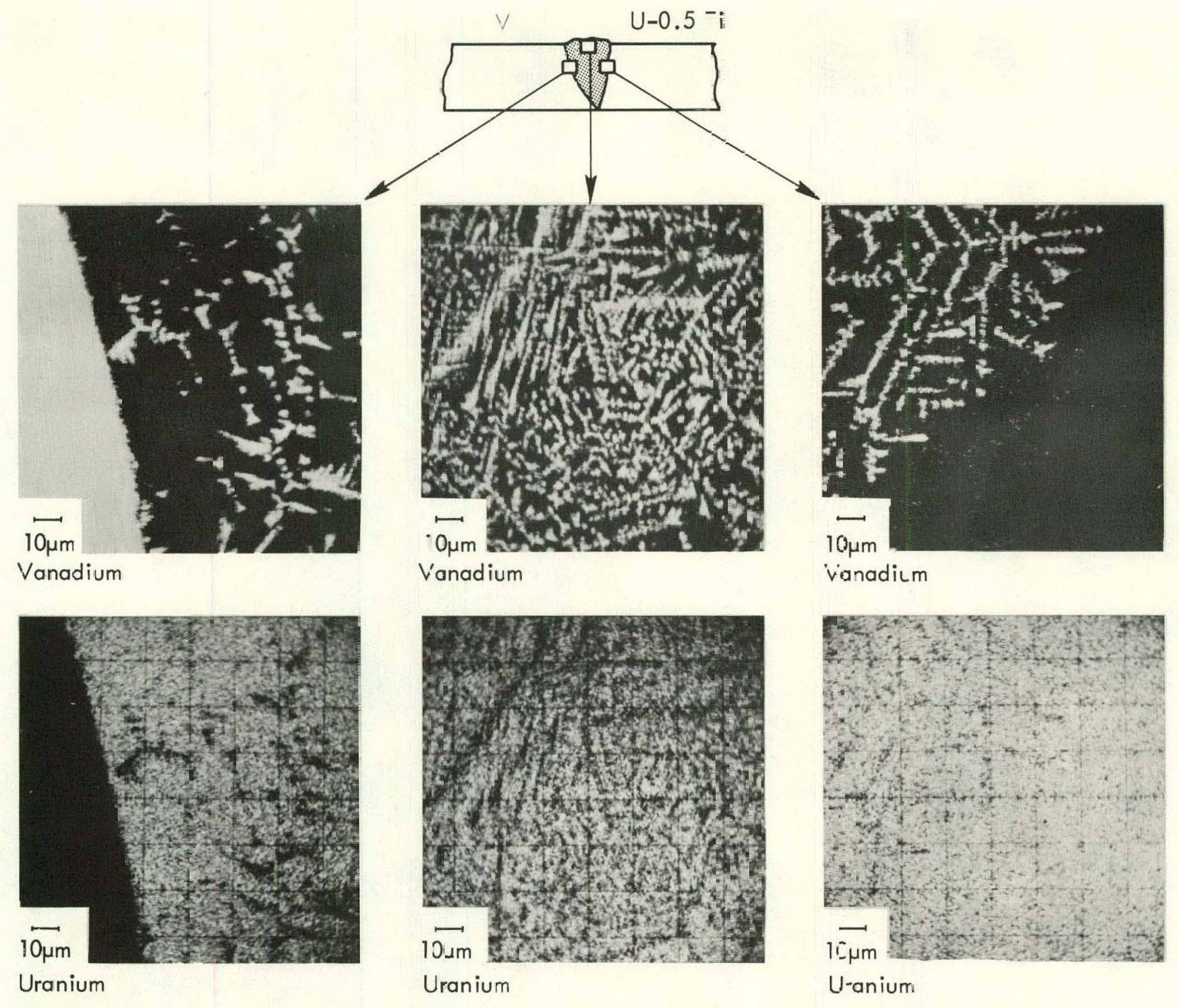

Figure 5. X-RAY VIDEOGRAPHS FROM THE WELD ZONE IN A URANIUM-J.5 TITANI UM/VANADIUM WE LD SPECIMEN. 


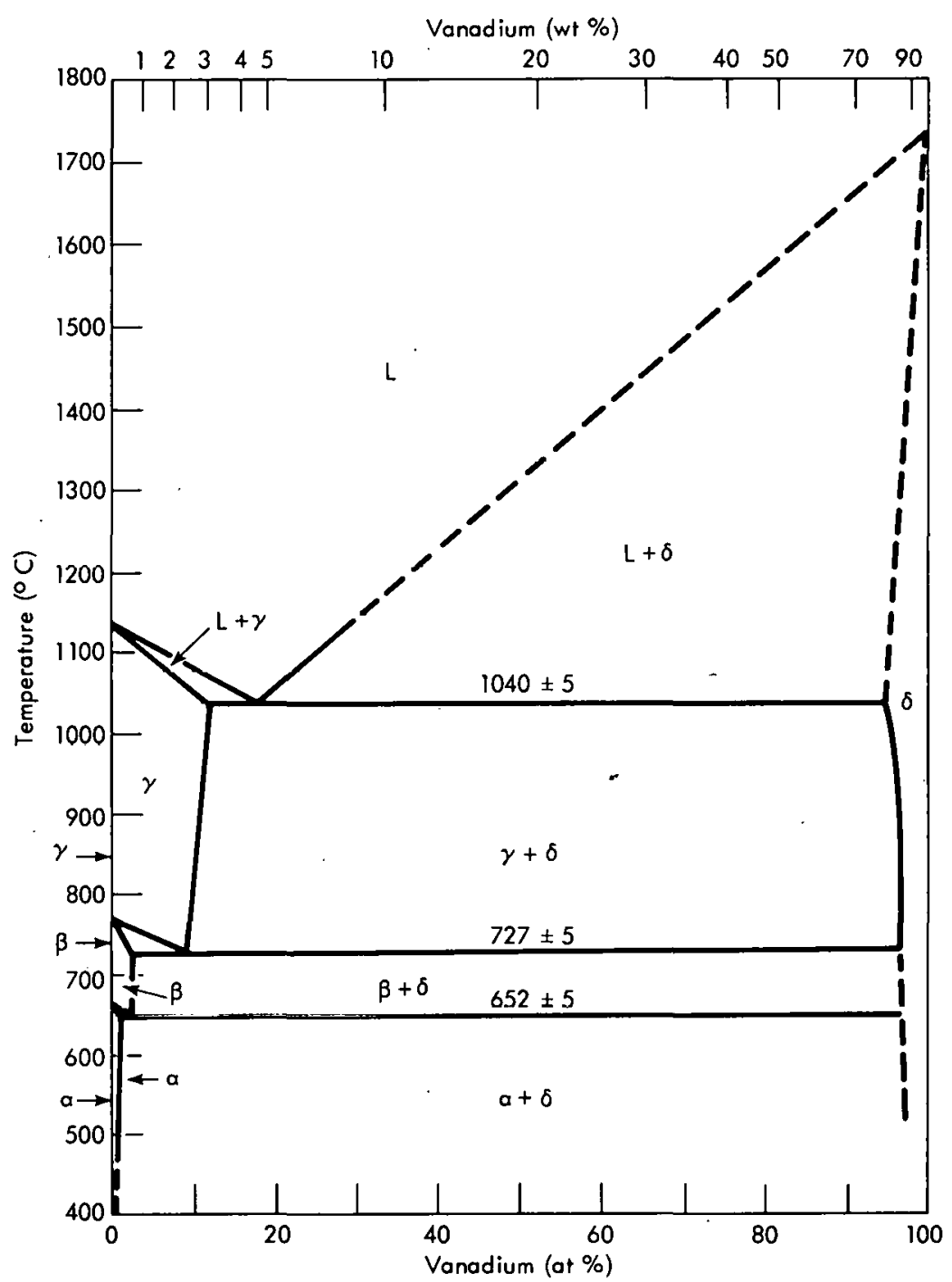

Figure 6. THE URANIUM-VANADIUM PHASE DIAGRAM. (Source: Hol$\operatorname{den}(1)$ )

welds were made with the following parameters: $100 \mathrm{kV}, 10 \mathrm{~mA}$, a sharp focus, and a travel speed of $76.2 \mathrm{~cm} / \mathrm{min}$. As was the case with the vanadium-uranium welds, high restraint was used to promote cracking if such a tendency existed.

The welds of 304L and 21-6-9 to vanadium all contained numerous transverse weld-metal cracks. This cracking was not expected since, as Figure 7 shows, vanadium and iron form a continuous solid solution and thus the compatibility should be good. Examination of the welds revealed extremely high hardness in the weld metal. Diamond-pyramid hardness values, using a 1000-gram load, were as follows:

\section{1-6-9 Base Metal}

194, 194, 206
Weld Metal

$.423,482$
Vanadium Base Metal

$127,127,120$ 


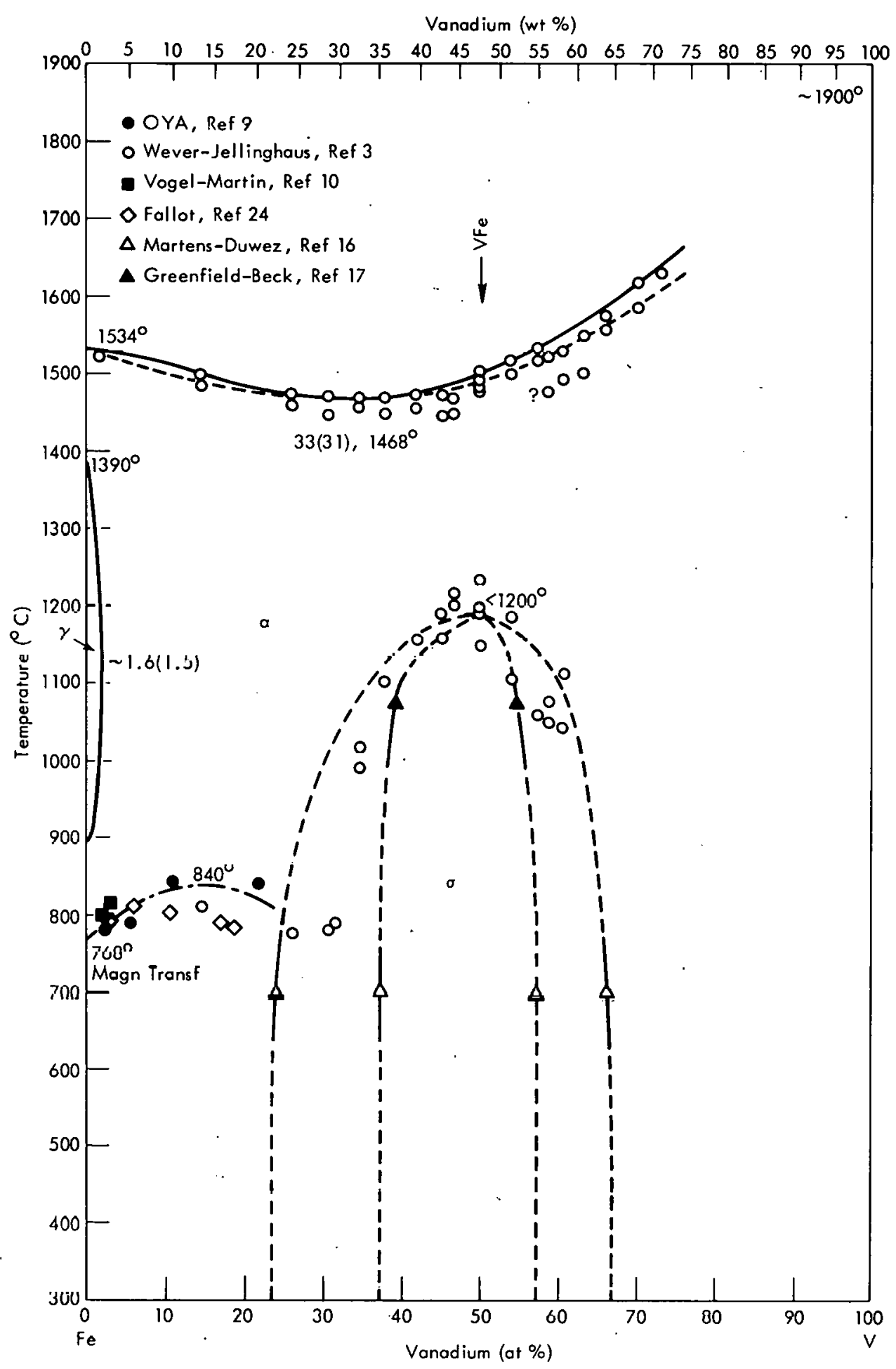

Figure 7. THE IRON-VANADIUM PHASE DIAGRAM. (Source: Hansen and Anderko(11))

304L Base Metal

$\mathrm{DPH}$

-
Weld Metal

461,461
Vanadium Base Metal

$136,132,124$ 
The high weld-metal hardness, coupled with the high restraint lof which transverse weld-metal cracks are an indication), was felt to be the cause of the cracking.

Due to the influence high weld-metal hardness and subsequent cracking could have on the development of usable vanadium-steel welds, indentification of the hardening mechanism was deemed to be essential. Three theories were postulated as possible hardening mechanisms in the vanadium-304L system: (1) solid solution hardening; (2) formation and dispersion of nickel-vanadium intermetallic compounds; (3) formation of the $\sigma$ phase in the vanadium-iron system.

Whenever two metals form a solid solution, the host lattice is distorted by the introduction of the foreign atoms, and hardening results. Solid-solution hardening reaches a maximum at a 50 - 50 at \% mixture because the lattice distortion is also at a maximum. Since these were welded butt joints between plates, the weld metal would be approximately a 50 - 50 vol \% mixture, or about 47 at \% vanadium and 53 at \% 304L. Lattice distortion would thus be approaching the maximum and, consequently, hardness would be approaching the maximum.

Reports in the literature of iron-vanadium welds $(12,13)$ have always been welds made with iron alloys which contained no nickel (low carbon steel, 410 stainless steel). Since both $304 \mathrm{~L}$ and 21-6-9 contain appreciable amounts of nickel (10.5 and $6.5 \%$, respectively), formation and dispersion of nickel-vanadium intermetallic compounds was postulated as a possible hardening mechanism.

Finally, as noted in Figure 7, the vanadium-iron system contains a rather extensive $\sigma$ phase which is like an intermetallic compound in properties-hard and brittle. However, the $\sigma$ phase in the vanadium-iron system is like other $\sigma$ phases in that it is a sluggish reaction, requiring long periods of time at elevated temperatures to occur. $(14,15)$ For this reason, appearance of the $\sigma$ phase in the weld metal would be highly unlikely and, therefore, this theory was discounted.

To evaluate which of the remaining two proposed mechanisms might be responsible for the hardening, pure iron was welded to vanadium. Again, the weld metal was hard.

\begin{tabular}{|c|c|c|c|}
\hline & Iron Base Metal & Weld Metal & Vanadium Base Metal \\
\hline PH் & $100,103,99$ & 464,464 & $142,147,141$ \\
\hline
\end{tabular}

In fact, the hardness increased slightly; however, this is easily explained. Since, in this case, there was no dilution due to an alloying addition to the iron, a $50-50$ at $\%$ mixture was more nearly achieved and a higher hardness resulted. With no nickel present to form nickel-vanadium intermetallic compounds; solid-solution hardening was determined to be the hardening mechanism.

Unfortunately, solid-solution hardening cannot be avoided; thus, some method of circumventing the hardening problem was necessary. Two methods appeared feasible for making usable iron-vanadium welds: (1) lower the degree of restraint; (2) vary the weld-metal composition to something other than a $50-50$ vol \% mixture. 
The high degree of restraint used to promote cracking in the previous welds may not be representative of the actual welding conditions. Welds were made between $304 \mathrm{~L}$ and vanadium with no restraint on the $304 \mathrm{~L}$ plates. These welds were crack free and transverse tensile specimens failed in the vanadium base metal with typical vanadium properties. Since there is a range of restraint where successful welds can be made (but this range cannot be easily measured quantitatively), the ability to make straight iron-vanadium welds can best be judged under actual fabricating conditions.

A second possible method for making iron-vanadium welds would be to control the metal dilution so that the weld metal would be of a composition of something other than a $50-50$ vol \% mixture. Welds of varying compositions were made by electron-beam welding butt joints of vanadium and $304 \mathrm{~L}$ plates. However, instead of aligning the electron beam directly on the joint, the $304 \mathrm{~L}$ side of the joint was favored. Relative weld-metal compositions were then determined by calculating what volume of each base metal had been melted and assuming that the agitation of the molten pool had resulted in good mixing. As seen in Figure 8 , the hardness of the weld metal can be controlled by controlling the weld-metal dilution. Welds which contained 40 and 34 vol \% vanadium were made using high restraint, and no cracks were detected in either weld. Thus, careful control of the weld-metal composition can allow usable iron-vanadıum welds to be made under high restraint.

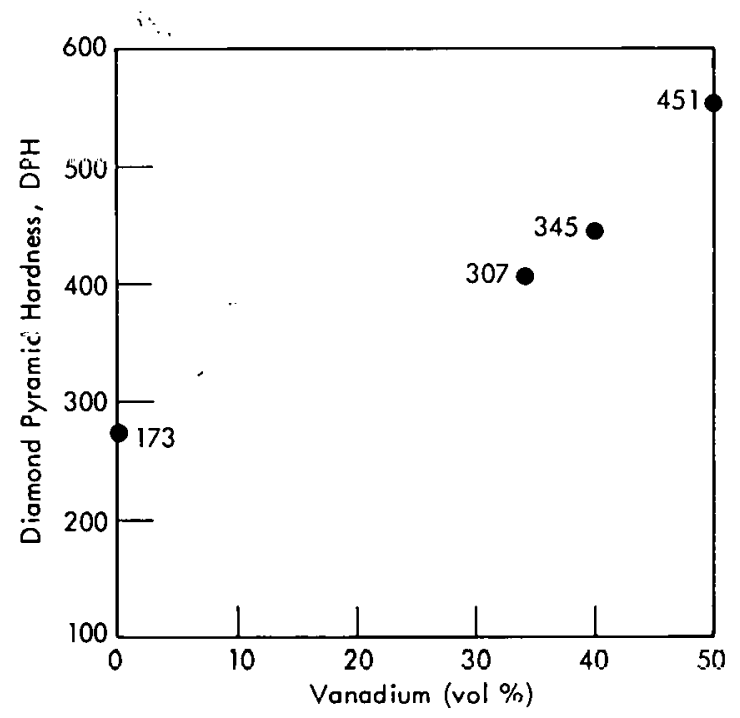

Figure 8. DIAMOND-PYRAMID HARDNESS AS A FUNCTION OF THE VOLUME PERCENT VANADIUM IN VANADIUM-304L WELOS.

\section{WELDING URANIUM TO STEEL}

Initial attempts to join uranium to $304 \mathrm{~L}$ steel were made by buttering approximately a 4.76- $\mathrm{mm}$ layer of vanadium onto uranium -0.5 titanium plates. The buttered layer was then ground flush and $304 \mathrm{~L}$ plates welded to them. High restraint and a misaligned beam were used for these welds. All welds made in this manner cracked. Two possible explanations for the cracking are that: (1) while the buttering was done in a glove box, the vanadium was contaminated during the buttering; or, (2) ineufficiont dilution of the uranium baغs metal occurred. Work was not done to further identify this problem.

Finally, a uranium- 0.5 titanium plate was joined to a $304 \mathrm{~L}$ plate by using a $4.76-\mathrm{mm}$ vanadium insert. The $\mathrm{U}-0.5 \mathrm{Ti}$ was first welded to the vanadium and then the $304 \mathrm{~L}$ joined to the vanadium using an offset electron beam. High restraint was used for both welds. Figure 9 is a photomicrograph of the complete transition joint; Table 7 lists the properties of transverse tensile specimens from the transition joint. All three tensile specimens failed in the vanadium insert. In addition, all the elongation occurred in the vanadium insert, as would be expected. While these results were satisfactory, this was not necessarily the optimum insert size. In fact, the size of the insert could at least be halved and still successfully used. 


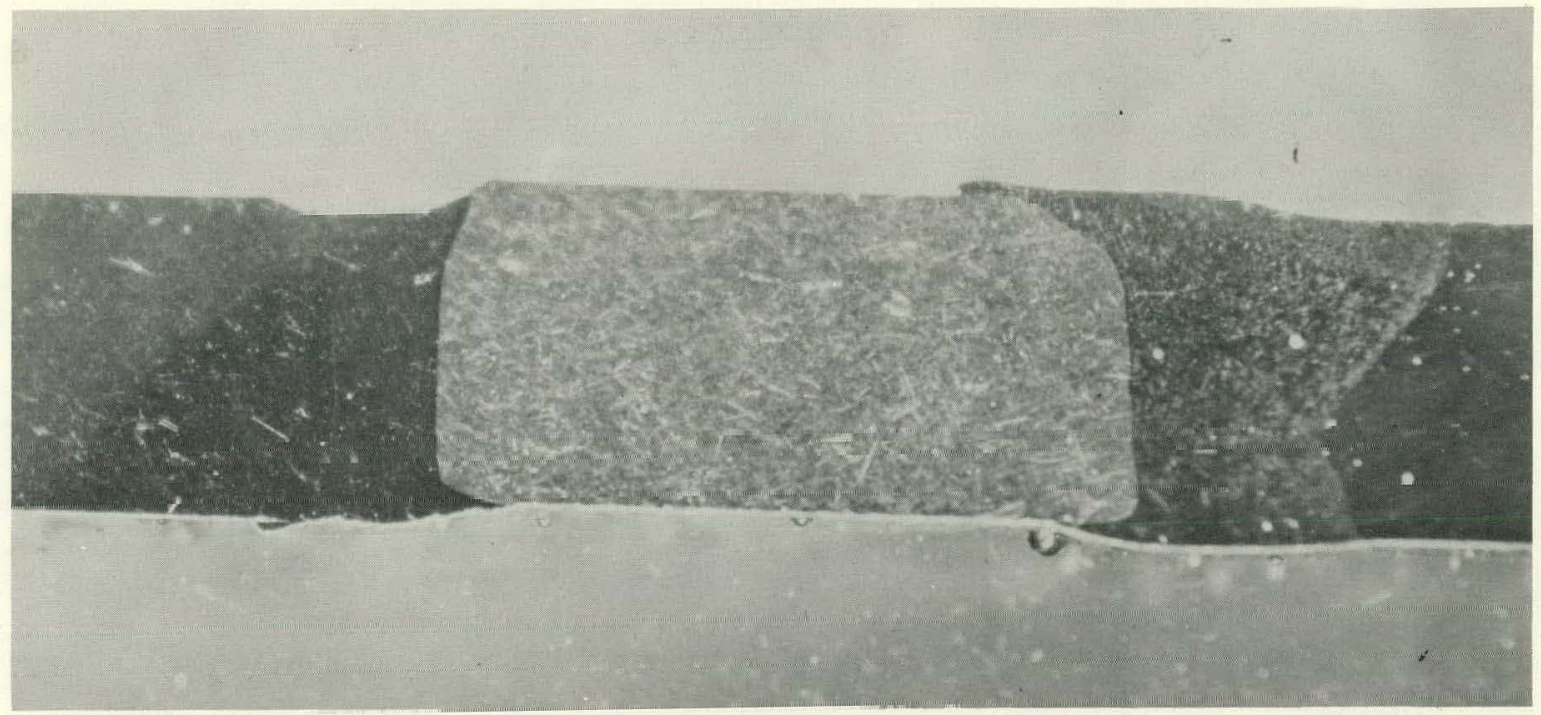

L299

Figure 9. URANIUM-0.5 TITANIUM/304L TRANSITION JOINT, USING A VANADIUM INSERT. ( $304 \mathrm{~L}$ on Left and U-0.5 Ti on the Right of the Insert; As Polished: Bright Field Illumination; 15X)

\section{CONCLUSIONS}

Use of vanadium as an intermediate material permits the joining of uranium to steel by fusion welding. This method is subject to the following limitations: (1) low joint restraint for welding, and/or (2) control of the iron-vanadium weld metal composition, (3) qualification of the joint for the intended service conditions.

The third limitation is very important because this work has not optimized the process in any manner; but, instead has presented a method which may deserve optimization. Considerably more work is necessary to characterize the welds and qualify them for some specific use.
Table 7

TRANSVERSE TENSILE PROPERTIES OF A URANIUM-0.5 TITANIUM/304L TRANSITION JOINT

\begin{tabular}{ccccc}
\hline & $\begin{array}{c}\text { Tensile } \\
\text { Strength } \\
(\mathrm{MPa})\end{array}$ & $\begin{array}{c}\text { Yield } \\
\text { Strength } \\
(\mathrm{MPa})\end{array}$ & $\begin{array}{c}\text { Elongation(1) } \\
(\%)\end{array}$ & $\begin{array}{c}\text { Location } \\
\text { of } \\
\text { Failure }\end{array}$ \\
\hline & 430.1 & 310.4 & 11 & V Insert \\
& 433.4 & - & 11 & V Insert \\
Average & 430.7 & 301.9 & 11 & V Insert \\
\hline
\end{tabular}

(1) In a 25.4-mm gage length. 


\section{REFERENCES}

(1) Holden, A. N.; Physical Metallurgy of Uranium, 1st Ed, pp 245, 257; Addison Wesley Publishing Company, Inc, Reading, Massachusetts (1958).

(2) Pumphrey, W. I. and Jennings, P. H.; "A Consideration of the Nature of Brittleness at Temperatures Above the Solidus in Castings and Welds in Aluminum Alloys", Journal of the Institute of Metals, 75, pp $235-256$ (1948).

(3) Pellini, W. S.; "Strain Theory of Hot Tearing", Foundry, 80, (11), pp $125-133$ (1952).

(4) Apblett, W. R. and Pellini, W. S.; "Factors Which Influence Weld Hot Crackıng", Welding Inurnal, 3.3. (2), Research Supplement pp 83-s - 90-s (1954).

(5) Borland, J. C.; "Generalized Theory of Super-Solidus Cracking in Welds (and Castings)", British Welding Journal, 7, (8), pp 508 - 512 (1961).

(6) Borland, J. C.; "Suggested Explanation of Hot Cracking in Mild and Low Alloy Steel Welds", British Welding Journal, 8 (11), pp 526 - 540 (1961).

(7) Turner, P. W.; Effect of Iron on Fissuring of Uranium Weld Metal, Y-1678; Union Carbide Corporation-Nuclear Division, Oak Ridge Y-12 Plant, Oak Ridge, Tennessee; August 11, 1969.

(8) Pattee, H. E., Evans, R. M., and Monroe, R. E.; "The Joining of Dissimilar Metals", DMIC S-16; Battelle Memorial Institute; January 1968.

(9) Darkin, L. S. and Gurry, R. W.; Physical Chemistry of Metals, pp 61, $77-109$; McGraw-Hill Book Company, Inc, New York (1953).

(10) American Welding Society, Welding Handbook, 6th Ed, Section 3A, p 47.44 (1970).

(11) Hansen, M. and Anderko, K.; Constitution of Binary Alloys, p 729; McGraw-Hill Book Company, New York (1958).

(12) Mitchell, D. R. and Kessler, H. D.; "The Welding of Tilaniunn lo Steel", Welding Journal, 40, (12), Research Supplement, pp 546-s - 552s (1961).

(13) Scott, R. W.; "Bonding Tilaniun! to Rene 41 Alloy", NASA Technical Brief B72-10041; Ames Research Center; October 11, 1971.

(14) Beck, P. A., et al; "Occurrence of CsCl-Type Ordered Structures in Certain Binary Systems of the Transition Elements", Transactions AIME, 206, pp 148 - 149 (1956).

(15) Beck, P. A. and Philip, T. V.; "CsCl-Type Ordered Structures in Binary Alloys of Transition Elements", Transactions AIME, 209, pp 1269 - 1271 (1957). 


\section{ACKNOWLEDGEMENTS}

The author wishes to acknowledge the assistance of B. G. Cross who did all the welding; members of the Development Metallography Laboratory who collected all the data, in particular J. A. Francis; J. E. Ferguson who did the microprobe analysis, and T. M. Mustaleski, Jr for his advice and consultation. 


\section{Distribution}

Energy Research and Development Administration - Oak Ridge

Hickman, H. D.

Leed, R. E.

Zachry, D. S., Jr

\section{Lawrence Livermore Laboratory}

Mara, G. L.

Robbins, J. L.

Los Alamos Scientific Laboratory

Hockett, J. E.

Sandstrom, D. J.

Oak Ridge Gaseous Diffusion Plant

Stief, S. S.

Wilcox, W. J., Jr

Oak Ridge National Laboratory

Slaughter, G. M.

\section{Oak Ridge Y-12 Plant}

Alvey, H. E.

Bernander, N. K.

Burditt, R. B.

Burkhart, L. E.

Dodson, W. H.

חiıggan. H. G.

Ebert, T. H.

Ellingson, R. D.

Fraser, R. J.

Gritzner, V. B.

I lubiei, R. A.

Jácksōn, V. C.

Jones, F. W.

K.ahl, K., G.

Keith, A.

Kite, H. T. (10)
Mills, J. M., Jr

Murphy, J. L.

Mustaleski, T. M., Jr

Perkins, M. A. (10)

Phillips, L. R.

Schreyer, J. M.

Scott, D. G.

Smith, H. F., Jr

Smith, R. D.

Stoner, H. H

Tewes, W. E.

Tilson, F. V.

Townsend, A. B.

Turner, P. W.

Yaggi, W. J./Googin, J. M.

$Y-12$ Central Files (5)

$Y-12$ Central Files (master copy)

$Y \cdot 12$ Centrál riles (ruule cuny)

$Y-12$ Central Files $(Y-12 R C)$

Zerby, C. D.

Paducah Gaseous Diffusion Plant

Levin, R. W.

Rockwell International - Rocky Flats

Jiannetti, E.

Sandia - Albuquerque

Navis, M. .I.

Sandia - Livermore

Adolphson, D. R.

US Army Ballistics Research Laboratory - Aberdeen Proving Ground

Gillich, W./Bloore, W.

In addition, this report is distributed in accordance with the category UC-38, Engineering and Equipment, as given in the USERDA Standard Distribution Lists for Unclassified Scientific and Technical Reports, TID-4500. 